\title{
Restatement And Accrual Basis Issue In Government Accounting in Indonesia
}

\author{
Erlynda Y. Kasim \\ PhD Student at Padjajaran University, \\ Lecturer at STIE Ekuitas Bandung \\ erlynda_kasim@yahoo.com
}

\begin{abstract}
Beginning of the year 2015, Indonesian Governmentstart to implement Accrual-based accounting. The government need to prepare the restatement of financial statement. This paper discuss what and how to prepare the restatement and also some issues in implementing the accrualbased accounting in government accounting.

Some chalanges find in implementing accrual-based government accounting are inadequate human resources capability, Information technology, funds, government support etc.
\end{abstract}

Keywords: Government Accounting, Accrual-based Accounting, Restatements, Financial reporting.

\section{Introduction}

The implementation of full accrual-based government accounting from cash accounting towards an accrual basis in Indonesia applies in the year 2015. This changes plays an important rolein Government Accounting asit concerns with the information generated from accrual accounting. This government financial information is expected to meet the objectives of decision-maker. Government accounting is closely associated with government finances (Tenry, 2014), so that the old systems and processes in government accounting generated a lot of obstacles that are not yet fully support for the establishment of good governance in government sector (Simanjuntak, 2012).

The changes in government accounting basis is an issue that much discussed nowadays. Reform was the first step towards the adoption of the accrual basis in budgeting. A change to the accrual basis has also been carried out in various countries with the depth and scope of different (Halim, 2014). From a budget perspective, most countries still apply the cash basis government accounting. Australia, New Zealand and the United Kingdom are now using the accrual basis in their budgets (Halim, 2014). While countries like the United States, Denmark, Netherland, Iceland and Canada only partially has already used the accrual basis governmental accounting.

Indonesia hasbeen trying various reform efforts in the fields of public management and financial responsibilityfor five years, Halim (2014). Various regulations issued aimed to better public management and financial accountability. Many researchhas been conducted relating to the public management field. Based on the literature, the main problem in the public finance managementare (Halim, 2014):
1. Accounting
2. Budgeting
3. Controlling
4. Auditing

The conceptual framework in government accounting standards plays an important role as a reference in preparing the government financial statements. Financial statement has to be prepared by the reporting entity. The reporting entity is a government unit consisting of one or more the accounting entity which is under the legislation shall submit an accountability report in the form of financial statements, consisting of:

a. Central Government

b. Local Government

c. State Ministry / Institution in the central government

d. The unit of organization in the central government / regions.

The conceptual framework also provides a basis for determining whether or not a financial statements has a good quality (Kieso, 2014). To assess the quality of the financial statements, the financial statements must meet the qualitative characteristics as mentioned in the conceptual framework:

a. Relevant

b. Reliable

c. Comparability

d. Understandability

The conceptual framework of government accounting are prepared not only for reference but also has oversight of the activities of public financial management and financial reporting (Scott, 2010). Government need to establish more public management supervision as the demands on accountability and transparency of the financial statements increased.

The release of Government Regulation (PP 24/2005)in Indonesia on the Government Accounting Standards is a new beginning for the implementation of the principles of state finances transparent and accountable. This State finances, which will be managed in separating the two, namely the central and regional, are expected to increasingly better in the future, at least in terms of regulations and implementation instructions (Shukri, 2009). The new Government regulation replaced the PP 24/2005 is PP $71 / 2010$.

The Government Accounting Standards in Indonesia was prepared by an independent committee called the Government Accounting Standards Committee (KSAP). KSAP establishment process is quite unique, so until now independence is still the subject of discussion (Bastian, 2006). Shukri (2009) states that in relation to this formation process, the KSAP stated that prior to the Law on State Finance determined, in accordance with the duties and functions of the Ministry of Finance in fiscal , Minister of Finance has set the finance ministerial decree No. 308 / KMK.012 / 2002 dated June 13, 2002 on the Accounting Standards Committee of Central and Local Government 
(KSAP), as amended by the Decree of the Minister of Finance No. 379 / KMK.012 / 2004 dated August 6, 2004.

Furthermore, in order to fulfill the mandate of Law No. 1 in 2004, it has been issued the Decree of the President of the Republic of Indonesia Number 84 of 2004 concerning the Government Accounting Standards Committee on October 5, 2004, as amended by Decree of the President of the Republic of Indonesia Number 2 of 2005 dated January 5, 2005.

The conceptual framework in the Public Sector Accounting Standards suggest the accounting basis used as cash and accrual basis. In 2010, the Government Accounting Standards Committee (KSAP) publishes accrual-based government accounting standards established by Regulation No. 71 Year 2010 concerning Government Accounting Standards replace Regulation No. 24 of 2005 which uses the cash basis towards accrual (Cash towards accruals).

There are just two kinds of cash basis and accrual basisin Accounting method. The cash towards accrual basis is the transition method from cash towards full accrual basis. The accounting basis is a method of determining as when and how to record economic transactions. Problems of recording lies in the differences in income and expense recognition. In a cash basis accounting, the transaction is not yet recognized /recorded until the transaction is actually received or released. If there is no effect on cash, the transaction is not recorded. Financial reporting generated by cash basis may be unreliable or does not meet the characteristics qualitative of financial reporting mentioned previously. Related to financial reporting of government, then the government's financial statements produced will be less reliable (less informative), (Halim, 2014). The uninformative reports will decrease the achievement the government goals in the transparent and accountable public management. Hence the application of the full cash-based accounting is no longer considered relevant with government relating good governance practice.

Accrual basis accounting recognizes the transaction and other events at the time of the transaction occur. Those transactions and events are recognized and recorded in the financial statements in the period incurred. For local governments that use full accrual accounting need to restatete the financial position in first year of changes the accounting basis.Restatement is prepared on items in the balance sheet at the beginning of the period when local governments implement new accounting policies changes from the original cash basis towards accrual becomes full accrual basis.Restatement required for balance sheet items that have not been following the policy of full accrual basis.

This paper discusses the restatement of government financial Balance reporting and other issue relating to the accounting basis change. As we know, the balance sheet is one component of the government's financial reporting which adheres towards the accrual basis of accounting. The discussion will begin with government financial reporting and discussion on the basis of accounting.The purpose of writing this paper is:

1. To find out how the Government Financial Reporting restatement related to the change from cash basis to accrual basis.

2. To discuss the restatement mechanism and whatshould be in preparing the financial statements on an accrual basis.

3. Data needed in the preparation of accrual-based financial statements restatement.
4. Discuss the obstacles that must be faced in the implementing accrual-based accounting.

5. Discuss the solution to these constraints.

6. Discuss the benefits of preparing restatements from cash basis to accrual basis of Government Financial Statements.

\section{Review Of Theory}

2.1. Financial Reporting

Basically all statements is a standard government accounting standards to prepare components of the government's financial statements, in which the components described in paragraph 28 Conceptual Framework of Government Regulation No. 71 Year 2010 as follows:

a. Budget Realization Report (LRA);

b. Statement of Changes in Surplus Budget(SAL);

c. Balance Sheet;

d. Cash Flow Statement;

e. Operational reports;

f. Statement of Changes in Equity;

g. Notes to the Financial Statements.

Paragraph 60 Conceptual Framework on Government Regulation (PP) No. 71 Year 2010 explained that the government's financial statements consist of statements implementation of the budget (Budgetary Reports), Financial Statements and Notes to Financial Statements. Budget Execution Reports consist of Budget Realization Report (LRA) and Statement of Changes in Surplus (SAL).

Financial report consists of the Balance Sheet, Statement of Operations, Statement of Changes in Equity, and Cash Flow Statement. Notes to the Financial Statements a report detailing or elaborate further on the post-post budget execution reports and financial statements and the reports are inseparable from budget execution reports and financial statements.

Here is an explanation table of financial statement items by category:

Financial StatementsCategories:

Budget Execution Reports(Budgetary reports):

1. Budget Realization Report (LRA)

2. Statement of Changes Over Time Budget (LP SAL)

Financial Statements

1. Statements of Operations (LO)

2. Balance

3. Statement of Cash Flow (LAK)

4. Statement of Changes in Equity (LPE)

Notes to the Financial Statements

1. Notes to the Financial Statements (CaLK)

Balance Sheetrequires restatement at the beginning of the accounting period when the change from cash basis to accrual basis towards accrual. Balance Sheet is the financial statement describes the financial position of an entity's assets, liabilities, and equity funds on a specific date.

\subsection{AccountingBasis}

Basis of accounting is accounting principles that determine when the effect of transactions or events should be recognized for financial reporting purposes. There are two Basis of accounting, which are cash basis and accrual basis. In cash basis accounting, economic transactions and other events are recognized when cash is received by the 
government's cash (Single Treasury / Regional Treasury) or paid from government coffers (State Treasury / Regional Treasury). Whereas in accrual accounting, economic transactions and other events are recognized and recorded in the accounting records and reported in the financial period at the time of the transaction, rather than when cash or cash equivalent is received or paid. Examples of transactions that differentiate the cash basis and accrual basis is the event when the government issued a Decree Determination of Tax (SKPP). In a cash basis, the publication of SKPP is not recognized as income, because the government has not yet received the cash. However, in the accrual basis, the date of SKPP issuance has been recognized by government as revenue, even though the government has not yet received the cash on the tax revenue.

As stipulated in Law No. 17 Year 2003 on State Finance and Law No. 1 year 2004 on State Treasury, the government is required to implement full accrual accounting basis for the recognition and measurement of revenue and expenditure budgets by the year 2008. PSAP No. 1 states that cash basis is used for the recognition of revenue, expenditure, transfer, and financing; and the accrual basis are for the recognition of assets, liabilities, and equity funds. Cash basis accounting is the basis which recognizes the effects of transactions and other events when cash or cash equivalent is received or paid. While the accrual basis of accounting is the basis which recognizes the effects of transactions and other events at the time of transactions and events that occur, regardless of when cash or cash equivalent is received or paid.

Reporting entities are allowed to prepare the accounting and presentation of financial statements using fully accrual basis, both in the recognition of revenue, expenditure, transfer, and financing, as well as in the recognition of assets, liabilities, and equity funds. On the other hand, the reporting entity is still present Budget Realization Report (LRA) based on the cash basis. Reconciliation of LRA accrual to cash-based LRA must be presented in the Notes to the Financial Statements (CaLK).Cash towards Accrual Basis is a temporary accounting basis implemented before fully accrual basis is implemented.

Reporting entities has to prepare the accounting and presentation of financial statements using accrual basis, both in the recognition of revenue, expenditure, transfer, and financing, as well as in the recognition of assets, liabilities, and equity funds. Reporting entity prepare and present financial statements on an accrual basis remained using cash basis in Actual Budget report.

\section{Discussion}

\subsection{Restatement}

Restatement is an improvement over the one or more financial reporting(dictionary investorwords (http://www.investorwords.com/6906/restatement.Html<Mar ch 21, 2015). Companies are asked to issue a restatement of a financial reporting that have been published previously because of several reasons, such as recording errors or mistakes of accounting fraud activit, a revision to one or more of a company's financial statements. A company may need to issue a restatement on its previously announced financial information for many reason including a simple calculation mistakes, or as a result of discovering fraudulent accounting activity.
Restatement is an accounting treatment of items in the balance sheet needs to be restated at the beginning of the period when the government for the first time will implement the new accounting policy from the Cash Towards accounting basis to fully Accrual Basis. Government Regulation No. 71 of 2010 PSAP 10 - paragraph 42 states that the change in accounting policy must be presented on the Statement of Changes in Equity and disclosed in Notes to Financial Statement (CaLK).

Restatement is required to adjust accounts in balance sheet items whichhave not followed the full accrual basis previously. The preparation of the balance sheet when it was first timeimplements the accrual basis is needed if the previous year-end balance still use the cash toward accrual basis. Based on this identification the following account is necessary to restate:

a. Receivables show the fair value after deducted byReceivables allowance;

b. Prepaid expenses, are previously recognized as expenditure, if still not fully expired, then records as a prepaid expense account. If it does not make an adjustments yet in the previous year, this account needs to be restated;

c. Inventories, in local government essentially is prepaid expenses. So it can be recorded as an asset or an expensesupon initial acquisition. Consumption of inventories should be recognized as an expense, while that is still not yetconsumed is recognized as an asset. This inventory account needs to be restated when the inventory valuation method in the prior period is not the same as the method of inventory valuation after implement the full accrual basis;

d. Long-term investment is restated when the previous recording method is different from the method used after an accrual basis. For example if there are investments in the previous period should already meet the listing criteria for using the equity method but still accounted for under the cost method, then it needs to be restated;

e. Fixed assets arereportedat the book value less accumulated depreciation;

f. Intangible assets, need to be restate which are the book value less accumulated amortization;

g. Debt interest need to be restated;it related to the interest accruefromthe short-term debt which is due;

h. Unearned income need to be restated for the prior period which have not been recorded;

i. Equity need to be restated because of the reclassification of equities.

\subsection{RestatementMechanism}

Steps that need to be done by the local government to restated balance sheet are:

1. Set up the data relevant to the recognition of related accounts as to calculate and recordthe provision of accounts receivable and allowance; depreciation expense and accumulated depreciation; amortization and accumulated amortization;

2. Restate re-balance sheet accounts that have not been adjusted to the accrual basis policies, in accordance with the Regulation of the Regional Head of accrual-based accounting policies.

3. Record Journal restatement in accordance with the accounts that require to restate. 
4. Prepare working paper to adjust the account that need to be restated.

5. Prepare Balance Sheet after restatement.

6. Prepare Notes to Financial Statements relates to accountrestatement.

\subsection{Data Needed In The Process Of Restatement}

For the preparation process of preparation of the restatement, the necessary data for preparation of restatement relates to the accounts to be adjusted, among others:

1. Current Assets Receivables

a. Data receivable and aging

b. Calculationof doubtful receivables estimation (ie. Using aging schedule)

c. Approximate calculations required for doubtful account.

d. Allowance for doubtful receivables included in Equity

2. Prepaid Expenses

a. Load data that has not been fully used. Eg prepaid insurance

b. Data load rental paid in advance and not yet a completely unused. Need to be re-pencatatatn if previously been recorded as an expense, it is necessary adjustments.

3. Inventories

a. Inventory data

b. Data reappraisal of the value of inventories at fair value or inventory taking a. Recalculation is required to view the fair value of inventories. Unused or load up on supplies.

\section{Short-Term Investments}

a. Data Short-term investments

b. Data in fair value (fair value) of short-term investments

5. Fixed Assets Fixed Assets

a. Fixed assets owned data

b. Data life of fixed assets

c. Data value of remaining life

d. Data used depreciation methods (straight line / Double declining balance) a. Necessary to establish the method of depreciation for each fixed asset

c. Necessary to establish the estimated residual value and economic life of the asset

6. Intangible assets

a. Data intangible assets owned

b. Data economic life of the intangible assets a. Necessary to establish the economic lives of intangible assets

7. Long-Term Investatsi

a. Data-owned long-term investment

8. Debt Short-Term Debt

a. Data and calculation of interest payable debt

9. Long Term Debt

a. Data and calculation of interest payable debt

10. Equity

a. Equity

\subsection{Chalanges In Implementing Accrual Based Accounting}

The process of preparing restatements certainly related to the constraints of the changes from cash basis toaccrual basis. Preparingrestatement technically related to the data collection of all components of balance sheet items such as assets, liabilities and equity. For example on account receivables, we need to estimate the amount of doubtful accounts.

While the general application accrual basis according toSyukry (2009) faces some constaints such as:

1. Inadequate human resources quality. This is a fundamental issue considering the mechanism of recruitment of civil servantswhich are still centralized. Regional expansion is another problem as the government has only limitedhuman resources.

2. Organizational Structure. According to Government Regulation PP No.41 / 2007, the local government has had to draw up the organizational structure (SOTK) in which there is morespace for new government accounting and management. However, the low quality and quantity of human resources in accounting raising a serious problem.

3. Regulatory Aspects. Inconsistency in the legislation related to accounting rule resulted in local government "lost appetite" to carry out accounting.

4. Aspects of socialization and mentoring. Socialization by the Ministry of Home Affairs, KSAP, CPC, and others have walked, but felt still very lacking. Funding is the main problem, followed by a location which is still remote. For example, very rare People form central government would do socialization to the Mentawai Islands (West Sumatera) or Bintang Mountains Regency (Papua Province).

5. The absence of reward and punishment. There is no sanction to the local government if it doesimplement SAP. BPK (Local Government Auditors)is usualyrequested by the Local Government act as a consultant or help to prepare his Financial Report (LKPD). Something which is certainly contrary to the regulations. What if the auditopinion on LKPD form of "qualified" or "disclaimer"? Is Regional Head received a disclaimer opinion may run again for the next 5 years election?

6. Willingness. Because the issues described above, plus the image that accounting would close the opportunity for fraudulent, then the local government seek justification for delaying the implementation of SAP.

Meanwhile, according Tenry (2014), some of the challenges the application of accrual accounting in the Indonesian government who can be identified, namely:

1. Accounting System and Information Technology (IT) Based System (Simanjuntak, 2010) and (Bastian, 2006). Given the complexity of the implementation of accrual accounting, it is certain that the adoption of accrual accounting in government accounting needsmore complicated IT and accounting systems. It also needs adequate internal control systems to provide reasonable assurance on the achievement of organizational goals through effectiveness and efficience, the reliability of financial reporting, security of state assets, and compliance with laws and regulations.

2. Commitment of Leadership. There must be commitment and political support from the decision makers, because the effort to apply accrual accounting requires substantial funds and a long period of time which is even longer than the time period of the presidency, governors, mayors, and members of the parlements(Ritonga ,2010).Strong support from the leadership is key to 
success of a change. One of the weakness of the preparation of financial statements in several ministries / institutions are due to weakness commitment of the leadership in particular Regional Work Units (SKPD). We need clear legislation to encourage the adoption of accounting rule and strong support from the leadership of ministries / agencies in central and Governor / Regent / Mayor.

3. Availability of Human Resources (HR) Competennce. Ritonga (2010) in Halim (2012) says it needs the support of competent and professional Human Resources (HR) in financial management. Preparation of financial statements requires HR which has capability in the area of accounting administration. Moreover, according Simanjuntak (2010) and Bastian (2006), these needs are due to the growing strength of government efforts to apply accrual accounting. Central and local governments need seriously planning of human resources in government accounting. Good system of incentives and remuneration are efforts to prevent corruption, collusion and nepotism $(\mathrm{KKN})$ by human resources associated with government accounting.

Training for stakeholders is needed to strengthen the competence of human resources and minimize the risk of unreliability financial data (Tenry, 2014). Training for implementing accrual basis are divided into 3 (three) level, ieTop level for politician or decision maker, Managerial Level and Technical Level. In general, through the Integration Socialization and Training Program is expected support the implementation of the accrual basis for all personnel and seek the achievement of the best audit opinion on LKKL (financial reporting) and LKPP.

4. Resistance To Change. In every change, there could be an internal party who are used to the old system and are reluctant to follow the changes. Therefore, policies needed to develop and carry out a variety of dissemination to all relevant parties, so that the implementation of accrual-based government accounting can run well without any resistance. The complexity of accrual-based accounting can lead to resistance, especially for the personnel preparing financial statements. There was also resistance from the legislature to adopt accrual budgeting as result of too complex accrual budgeting.Halim (2014) finds that the difficulties in the application of accrual-based budgeting is discipline. Decision to spend money should be matched with the period of expenditures reported in the budget report.

5. Society and environment. Support from the community is needed to achieve successful implementation of government accounting. People should be able to understand the government's financial statements, and concerns the use of tax they pay as well as the allocation of existing resources. The positive support from community encourages the government to be more transparent and accountable in implementing its policies.

6. Funding. In the framework of the implementation of the accrual-based accounting, the Government requires significant funds to conduct training and personnel recruitment by considering the number of work units $( \pm$ 24,000) spread throughout Indonesia. Additional funds needed from the state budget and grant from international institutions, such as GPF-AIP program and the World Bank.

7. The application of accrual accounting causes a decrease in equity as a result of depreciation and amortization, where it will be reflected in the book value of government financial statements.

8. The application of accrual-based accounting may result decreasing the financial statements quality (lower audit opinion quality of LKKL and LKPP).This is possible to happen if the government is not anticipating the impact of complexityaccrual-based financial statements

3.5. Solution To Face Challenges In Restatement And The Implementation Of Accrual-Based Government Accounting

Chalanges in the preparation of restatements can be overcome with a few things to do with the readiness of government accounting standards change from the cash basis into the accrual basis. Ritonga (2010) describes a solution in the face of these constraints is the creation of conditions that support this issue include:

1. Support in competent and professional Human Resources (HR) in the financial management.

2. Support from the financial statementsauditor, due to changes in accounting basis which change the way the examination conducted by the examiner. The changes that occur must be through the consideration of the Supreme Audit Agency (BPK).

3. Availability of Technology Information Systems which has to be able to accommodate the requirements of accrual accounting system.

4. The existence of accrual-based budgeting system. It would be uncomparable between budget and realization if the budget revenues, expenditures, and financing is still cash bases, while the realization is accrual bases.

5. There must be a commitment and political support of the decision makers in government. The effort to apply accrual accounting requires substantial funds and a long time period

One of the important points in the implementation of accrual-based accounting is also to be applied to the accrual-based budgetingTenry (2014). Accrual-based budgeting is difficult to apply in government organizations because of the complexity of implementing it. Budgetary accounting requires the recording and presentation of accounts both in operation and the budget statement. Government currently trying to address this problem by building a Treasury System and the State Budget (SPAN), which is an information technology-based system intended to support the achievement of the basic budget management. The whole process related to budget management that includes budgeting, budget document management, management commitment to procurement, payment management, revenue management, cash management and reporting integrated into SPAN. Significant changes are demanding in improvements of business processes and changes the mindset of the parties involved in the business process.

The use of highly reliable technology required to support the success of data processing either in transition or during the implementation of full accrual basis (Tanry, 2014). Preparation in the field of information technology is mainly directed to the development of accounting systems. 
Development of accrual-based accounting system requires an accounting system to accommodate it. The Ministry of Finance has developed SPAN (Treasury System and the State Budget) whichwas launched on August 19, 2013. Government also developMAGIC (Accounting System Level Institutions). This system has been carried out stages Integration Test and piloting system planned 2014.Opportunity government in organizing the accrual accounting Tenry discussed by, among others, are:

1. Mandate Law 17/2003 and Law No. 1/2004 and CPC recommendations in the application of accrual accounting

2. High commitment of the leadership of the country organizing

3. Experience in developing and preparing accounting systems and application-based financial statements Cash Towards Accrual

4. Experience in preparing human resources accounting and financial reporting by the Government Finance Accountability Acceleration Program (PPAKP)

5. The availability of human resources in sufficient numbers who understand accounting based CTA

6. The experience of the Ministry of Finance in the development and dissemination of accounting and finance to all state ministries / agencies

7. More effective decision-making that has been getting more comprehensive information

8. The commitment of help and support from friendly countries and international institutions, such as from Australia via GPF-AIP program and the World Bank.

\subsection{Benefits Of Using Accrual Basis}

Preparation of restatement of balance sheet at the beginning of the period intends to show the real financial position of local governments as it uses accrual-based accounting. With the restatement, the process of using the accrual basis of accounting can be applied entirely on the financial statements. In general, the benefit of using accrual based accounting rather than cash-based accounting:

1. Revenue expenditure and financing are recognized and recorded when timbulya rights and obligations regardless of the cash is received / issued.

2. Presentation of the assets in the balance sheet reflects the net value taking into account depreciation and allowance.

3. Provide a complete picture on the financial position of local government

4. Presenting the actual information about the rights and obligations of local government

5. Control the budget deficit and the accumulated cost of government better

6. Helpful in evaluating the performance of government services related costs, efficiency and the achievement of objectives.

\section{References}

Abdul Halim, Public Sector

2014.

Directorate General of Regional

Accounting, Salemba 4,

Finance,

Accounting Module Overview Accrual- Based http://keuda.kemendagri.go.id/a

sset/dataupload/paparan/papara akrual/GAMBARAN-UMUM-

n-modul-sap-

MODUL-

AKPEMDA-BSS- AKRUAL.pdf (Downloaded

March 20, 2015)

InvestorwordsDictionary, http://www.investorwords.com/ 6906/restatement.html <March 21, 2015

Margono, Regions Financial Accounting module, WidyaswaraPusdiklat State assets and

financial Balance $\quad 2010$

Indonesian Government Regulation $\quad$ Number 24

Year 2005 concerning Government Accounting

Standards

Indonesian Government Regulation $\quad$ No. 71 Year Government Accounting 2010 Tentang

StandarAkuntansi

Ritonga, Rahmansyah. Cash Basis vs Accrual Basis. Widyaiswara BDK. Field.

Syukry, Constraints SAP Implementation by Local Government, https://syukriy.wordpress.com/ 2009/02/26/kendala-penerapan- sap-olehpemerintah- daerah/ (downloaded: 9 Aprli 2015)

TenryNurAmriani, Meyongsong Akuntnsi Accrual Based Government, http://www.bppk.kemenkeu.go. id/beritamakassar/19410- menyongsong- penerapanakuntansi-pemerintahan- berbasis-akrual.

(Downloaded: 9 april 2015)

Tiron Tudor, Adriana and Mutiu, Alexandra, Cash Versus Accrual Accounting in Public Sector.Studia Universitatis Babes Bolyai Oeconomica, 1990. Available at SSRN: http://ssrn.com/abstract $=90683$ 